\title{
UPAYA ORANG TUA MENGEMBANGKAN KECERDASAN EMOSIONAL ANAK DALAM KELUARGA MUSLIM DI PERKAMPUNGAN KODAM I/BB MEDAN SUNGGAL
}

\author{
${ }^{1}$ Saiful Akhyar Lubis, ${ }^{1}$ Nurrusakinah Daulay, ${ }^{1}$ Joni Ahmad, Rahmadi Ali ${ }^{2}$ \\ ${ }^{1}$ Universitas Islam Negeri Sumatera Utara \\ ${ }^{2}$ Universitas Muslim Nusantara Al Washliyah Medan
}

Email: ${ }^{1}$ Zhoniahmad@gmail.com, ${ }^{2}$ rahmadi.ali2121@gmail.com

\begin{abstract}
Abstrak
Peranan orang tua dalam mengembangkan kecerdasan emosional sangatlah diperlukan untuk perkembangan anak disetiap usianya oleh karena itu penelitian ini bertujuan untuk 1.) upayaupaya apa saja yang dilakukan orang tua dalam mengembangkan kecerdasan emosional anak 2.) mengetahui aspek apa saja yang dikembangkan dalam keluarga 3.) Mengetahui faktor penghambat dan pendukung dalam mengembangkan kecerdasan emosional anak dalam keluarga. Penelitian ini menggunakan metodologi penelitian kualitatif dengan pendekatan fenomenologi, adapun desain yang digunakan adalah studi lapangan (riset), Pengumpulan data dilakukan melalui wawancara, obserasi/pengamatan dan dokumentasi sedangkan untuk analisisnya, penulis menggunakan teknik analisis diskriptif kualitatif yaitu berupa data-data yang tertulis atau lisan dari orang dan perilaku yang diamati, dalam hal ini peneliti berupaya mengadakan penelitian yang bersifat menggambarkan secara menyeluruh keadaan yang sebenarnya. Dari hasil penelitian maka dapat diambil kesimpulan bahwa upaya-upaya yang dilkaukan orang tua dalam mengembangkan kecerdasan emosional anak dalam keluarga di perkampungan KODAM I/BB Medan Sunggal berpengaruh besar pada perilaku dan pendidikan yang diberikan oleh orang tua sejak awal masa pertumbuhan anak, sehingga ketika anak beranjak dewasa dapat mengelola emosi dengan baik, dan upaya lainnya yang dilakukan orang tua dengan membuat jadwal khusus bersama anak, memotivasi anak dan membimbing anak.
\end{abstract}

Kata Kunci: Kecerdasan Emosional; Upaya Orang Tua; Anak

\begin{abstract}
The role of parents in developing emotional Intelligence is necessary or the development of children at every age, therefore this study aims to 1.) what efforts are made by parents in developing children's emotional intelligence 2.) knowing what aspects are being developed in family 3.) Knowing the inhibiting and supporting factors in developing children's emotional intelligence in the family. This study uses a qualitative research methodology with a phenomenological approach, while the design used is a field study (research), Data collection was carried out through interviews, observation / observation and documentation, while for the analysis, the researcher used qualitative descriptive analysis techniques, namely in the form of written or oral data from people and observed behavior, in this case the researcher tried to conduct research that was to describe thoroughly the situation. which is actually. From the results of the study, it can be concluded that the efforts made by parents in developing the emotional intelligence of children in Muslim families in the KODAM I I BB Medan Sunggal Village have a major effect on the behavior and education provided by parents from the beginning of the child's growth period, so that when growing up children can manage emotions well, and other efforts made by parents by making special schedules with children, motivating children and guiding children.
\end{abstract}

Keywords: Emotional Intelligence; Parental efforts; child 


\section{Pendahuluan}

Tujuan dari pendidikan paling utama adalah mengembangkan dan mencerdaskan kehidupan bangsa seutuhnya, yaitu manusia yang berpengetahuan dan beriman, memiliki ketrampilan dan berakhlak, sehat secara jasmaniah dan ruhiah mempunyai kepribadian yang baik serta bertanggung jawab terhadap diri dan lingkungan disekitarnya dalam bermasyarakat. Pada umumnya pendidikan dasar dimulai dari keluarga, sikap, perilaku, ataupun sifat seseorang merupakan hasil dari didikan ayah dan ibu kepada anaknya sebab keluarga adalah sarana awal bagi anak untuk memulai mengenal proses kehidupan.

Keluarga adalah kelompok kecil yang merupakan bagian dari masyarakat menjadi kelompok kecil yang didapati dua orang yang menjadi pasangan yang memiliki peranan sebagai suami atau ayah kemudian didampingi oleh seorang istri atau ibu serta memiliki beberapa individu yang tinggal bersama di bawah satu atap rumah yang sama dimana mereka memiliki kondisi saling membutuhkan dan ketergantungan anatara satu dengan yang lainnya. (KBBI, 2013).

Berkaitan dengan sifat, sikap, dan perlaku anak yang baik maupun buruk merupakan suatu pengendalian diri yang disebut sebagai emosional, orang yang memiliki kecerdasan emosional mampu mengendalikan dan mengekspresikan diri di berbagai macam situasi, serta mampu bersosialisasi dengan orang lain dengan baik.

Kecerdasan

emotional

quetiont atau EQ adalah kemampuan yang dimiliki seseorang untuk menggendalikan diri, nafsu, dan emosi serta pengetahuan tentang dirinya sendiri. Dalam hal ini yang dimaksud pengetahuan tentang diri sendiri bukanlah tentang diri yang bersifat fisik, seperti warna kulit, bentuk rambut, tinggi badan, yang berkaitan dengan kedirian melainkan pengetahuan tentang potensi dan kemampuan yang ada pada diri snediri, mengetahui kelemahan dan perasaan atau emosi diri, oleh karena itu seorang individu mestinya memanfaatkan, mengekspresikan, mengendalikan dan juga berkomunikasi dengan berbagai pihak lainnya. Seorang individu yang memiliki kecerdasan emosional pada umumnya ialah orang yang mempunyai kemampuan untuk memecahkan masalah, kemandirian, memiliki rasa empati, keramahan dan sikap hormat, sedangkan kunci kecerdasan emosional ialah kesabaran. (Djamarah, 2004)

Dapat disimpulkan bawa kecerdasan emosional merupakan kemampuan dari setiap individu untuk menguasai diri, menerima, mengelola, mengontrol emosi yang ada pada dirinya dan orang lain, di mana kecerdasan emosional ini mengacu pada perasaan terhadap suatu informasi dalam setiap hubungan, perasaan yang dimaksud seperti gembira, marah, putus asa, benci, tidak suka/senang dan banyak al yang berkaitan dengan emosi diri, sebagaimana yang peneliti temukan sebelumnya pada fenomena lapangan yaitu:

a. Pengaruh positif kecerdasan emosional bagi anak diantarnya yaitu, anak akan lebih mengenal emosi pada diri dan kesadaran pada diri sendiri mampu 
mnyesuaikan diri terhadap perasaan yang sebenarnya terjadi, mengendalikan dan mengurangi emosi negatif pada diri sendiri seperti marah, cemas atau depresi, anak yang memiliki kecerdasan emosi tentunya memiliki rasa empati dan mudah bergaul antar sesama teman, sebagaimana yang peneliti temukan dilapangan, anak-anak lebih memiliki motivasi dalam belajar, saling berbagi antar teman, membantu teman dalam kesulitan, anak lebih bersikap proaktif terhadap teman yang suka menggangu dirinya, ketika dalam masalah yang menegangkan dan tidak sulit bagi anak untuk menyelesaikan permasalahan, anak lebih memilih menceritakan kepada orang tua dan orang tua yang baik dalam mendidik emosional anak akan memberikan arahan yang sangat baik, sebagaiamana akan peniliti kupas pada bab berikutnya.

b. Pengaruh negatif bagi anak yang tidak memiiki kecerdasan emosional, yaitu anak tidak akan mampu mengatasi emosi pada dirinya yang akan berujung stres, stres yang tidak terkendali membuat mental lemah yang berdampak bagi anak mengalami kecemasan dan depresi, sebagaimana yang peneliti temukan di lapangan, bahwa dampak di atas tergambarkan terhadap diri anak yang merasa tertekan oleh teman, teman yang suka menyudutkan, mengejek, dan menjahili, membuat anak tersebut menyendiri, memisahkan diri dari teman yang lain, merasa tertekan dan sulit untuk bergaul yang berujung berdampak stres, bahkan dapat menghambat atau mengganggu konsentrasi belajar apa bila sedang mengalami ketegangan emosi belajar, kemudian anak yang memiliki kecerdasan emosional rendah akan lebih bersikap reaktif terhadap teman yang sering memicu emosi seperti mudah marah, pada akhirnya anak suka berkelahi antar teman, anak akan merasa hebat terlebih lagi anak yang berasal dari keluarga militer, dan hal inilah yang membuat anakanak dari kalangan militer menjadi nakal..

Kecerdasan emosional anak sangat penting untuk dikembangkan sebab kecerdasan ini tidaklah berkembang secara alami. Kematangan emosi anak tidaklah semata-mata mengikuti perkembangan biologisnya, tetapi tergantung pada proses pendidikan atau cara mengasuh anak yang dilakukan kedua orang tua, bimbingan dan pelatihan yang dilakukan secara terus menerus. Emosi yang dimiliki oleh anak sering berbeda jika dibandingkan dengan orang dewasa, terlebih bila anak yang sudah beranjak ke usia remaja. Ciri khas emosi anak ialah emosi marah dan takut berlebihan, ini yang menyebabkan faktor fundamental bagi emosional anak. (Lestari, 2016)

Masa remaja merupakan masa yang banyak mengalami perubahan pada diri anak, pertumbuhan dan perkembangan yang ada pada diri anak sangat mempengaruhi cara anak berinteraksi dengan orang lain. 
perkembangan emosional yang terjadi pada remaja dan sering kali sulit untuk dikendalikan ialah rasa sedih yang berlebihan, ketakutan, marah, malu, kenikmatan dan cinta. Faktor lain yang mempengaruhi kecerdasan emosional anak ialah bagaiamana cara orang tua mendidik anak dari kecil yang mempengaruhi perkembangan emosinya.

Perkembangan kecerdasan emosional anak tidak berpengaruh besar dari lingkungan masyarakat atau sekolah apa bila dibandingkan pengaruh dari dalam keluarganya sendiri, seorang anak yang sudah didik dari keluarga, akan sangat mudah untuk diarahkan kepada perbuatan yang mengandung kebaikan, dan akan sangat kokoh bila ada pengaruh negatif dari sisi lain, baik dari sekolah maupun lingkungan sekitarnya. (Moh, 2017)

Peran emosi dalam proses pembelajaran memberi pengaruh yang cukup berdampak terhadap porses pembelajaran pada diri anak. Emosi pada diri anak akan sangat berpengaruh untuk memabantu proses belajar yang memiliki makna dan menyenangkan pada anak, dalam pandangan beberapa ahli bila tidak adanya keterkaitan emosi, saraf pada otak tidak akan berproses secara maksimal dan tidak akan optimal dalam menggali ilmu pengetahuan pada ingatan sehingga apa yang dihasilkan pada proses pembelajaran tidak bisa dicapai secara sempurna.

Keberhasilan seseorang sangat berpengaruh dari pengendalian emosinya, sebab kecerdasan seseorang dalam mengelola emosi dapat membantu proses belajar agar lebih cepat dan menghasilkan pencapain yang sempurna, berlaku pula kebalikannya orang yang gagal dalam mengelola emosi menyebabkan perlambatan belajar bahkan dapat menghentikan proses belajar anak. Oleh karena itu keberhasilan dalam proses pembelajaran mestinya diawali dengan mengembangkan emosi yang baik atau berbentuk positif pada anak didik. Bahkan dari yang sederhana ini dapat menciptakan suasana pembelajaran yang menyenangkan (Almaja, 2017)

Dari pengamatan peneliti di perkampungan militer (tentara) KODAM I BB Medan Sunggal kanan, peneliti menemukan ada beberapa faktor yang dialami oleh anak dalam keluarga militer (tentara) khususnya dalam kecerdasan emosionalnya, dalam rana pendidikan sebagaiamana kedua orang tua dalam keluarga militer mendidik anak dengan beragam cara, ada yang menggunakan cara otoriter, demokrasi otoriter, ataupun memanja tergantung pada kedua orang tua. dari beragam pola asuh/mendidik anak remaja yang sedang bertumbuh kembang akan membawa dampak terhadapnya baik positif ataupun negatif, tergantung bagaimana upaya orang tua mendidik dan mengembangkan emosional anak yang sedang berkembang.

$$
\text { Keluarga merupakan }
$$

lingkungan awal yang dikenal oleh anak, keluarga adalah bentuk kekerabatan terkeil dimana anak dapat melakukan interaksi sosial. Anak mendapatkan pendidikan pertama kalinya ialah dari kedua orang tuanya sebagaimana dikenal dengan pendidikan informal. Keluarga berperan penting untuk membentuk kepribadian yang matang 
dan mengembangkan kecerdasan emosional pada diri anak, sebab anak memiliki waktu yang cukup banyak bersama keluarga jika dibanding sekolah dan lingkungan sekitarnya.

Dari apa yang telah dipaparkan pada pendahuluan, untuk itu peneliti tertarik dan ingin melakukan kajian tentang upaya orang tua mengembangkan kecerdasan emosional anak dalam keluarga muslim di perkampungan KODAM I/BB Medan Sunggal. Kecerdasan emosional sangat efektif untuk dikembangkan apa bila orang tua yang berperan aktif dalam mendidik anak agar memiliki kemampuan dalam mengenal emosi, mengontrol diri, memiliki rasa empati, dan mampu bersosialisasi dengan baik, dengan demikian sedikit banyaknya peneliti telah menemukan fenomenologi dilapangan dan akan diteliti lebih dalam pada penelitian ini.

\section{Metode Penelitian}

Pada penelitian ini metode yang digunakan adalah metode kualitatif dengan pendekatan fenomenologi, desain yang digunakan ialah studi lapangan (riset). Metode kualitatif digunakan untuk menyajikan dunia sosial dan perspektifnya di dalam dunia dari segi konsep dan persoalan tentang manusia yang ditleiti, penggunaan pendekatan fenomenologi sendiri bertujuan untuk memahami dan menjelaskan secara rinci pengetahuan mengenai upaya orang tua mengembangkan kecerdasan emosional anak dan pola asuh serta alasan mengapa individu memilih pola asuh tersebut untuk diterapkan di dalam keluarganya. Pendekatan fenomenologi ialah menghubungkan pengetahuan ilmiah dengan pengalaman sehari-hari dan kegiatan dari mana pengetahuan itu berasal.

Sumber acuan data yang digunakan pada penelitian ini dibagi menjadi dua yaitu, sumber data utama (primer) diperole melalui responden atau kedua orang tua di perkampungan KODAM I/BB Medan Sunggal. Kemudian sumber data yang kedua (sekunder) diperole dari kepala lingkungan KODIM serta dokumendokumen yang ada di Kantor KODIM mengenai perkampungan militer (tentara) KODAM I BB Medan Sunggal yang bisa dijadikan sebagai informasi atas kegiatan penelitian tersebut.

Subjek penelitian ialah informan yang ada di latar belakang penelitian untuk menggali informasi yang dibutukan, apabila subjek subjek penelitian terbatas dan masih berada dalam jangkauan sumber daya maka dapat menggunakan studi populasi. (Prastowo, 2014) jadi syaratnya ia harus memiliki pengalaman yang berkaitan dengan penelitian. Maka dalam penelitian ini yang menjadi informan ialah 5-10 keluarga muslim yang memiliki anak usia 7-13 tahun yang terdapat di perkampungan militer (tentara) KODAM I BB Medan Sunggal, yang dianggap peneliti layak untuk dijadikan sumber penelitian berdasarkan latar belakang orang tua yang berbeda, yang berlamatkan di perkampungan tersebut.

Dalam pelaksanaan penelitian kualitatif ini, peneliti adalah instrumen utama (Key Instrumen), pengemupulan data yang dilakukan oleh peneliti untuk mengetahui dan menerangkan tentang kapan, dimana 
dan bagaimana penellitian akan berlangsung, pada penelitian kualitatif dilakukan oleh peneliti untuk tanya jawab (wawancara), observasi/pengamatan dan pengumpulan data-data yang bertujuan untuk mencatat peristiwa. (Syaukani, 2018)

Data penelitian kualitatif ini akan peneliti lakukan secara terus da berulang-ulang dari awal penelitian hingga selesai sampai akhir, kemudian menemukan hal apa saja yang dapat dipelajari kemudian membuat keputusan apa saja yang dapat diceritakan kepada informan, setelah itu data dianalisis menggunakan teknik yang dinyatakan oleh miles dan huberman yaitu: pengumpulan data, penyajian data, reduksi data dan menarik kesimpulan, dimana hal ini akan terjadi berulangulang ketika data yang disajikan tidak sesuai atau sejalan dengan kesimpulan. (Sugiyono, 2015)

Berikut adalah gambaran dari hasil data dan model interaktif menurut miles dan Huberman dalam (Sugiyono : 2015) untuk proses pengumpulan data.

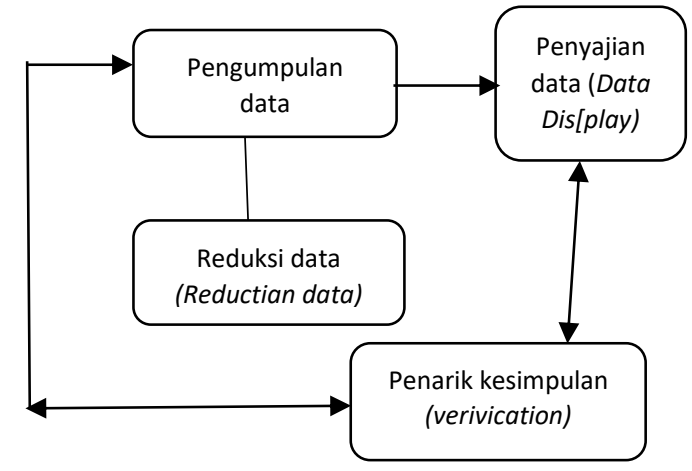

Gambar. Analisis Model Interaktif

\section{Hasil dan Pembahasan}

Hasil penelitian yang berjudul "Upaya orang tua mengembangkan kecerdasan emosional anak dalam keluarga muslim di pekampungan KODAM I Medan Sunggal", akan dibahas secara rinci pada bagian pembahasan penelitian ini didasarkan pada hasil dari data temuan umum dan khusus serta mengaitkannya dengan teori yang sudah ditetapkan sesuai dengan tema penelitian.

Penduduk yang teradapat pada perkampungan KODAM I Medan Sunggal berdasarkan data yang terdapat pada temuan umum berjumlah 5.755 jiwa. Perkampungan KODAM I Medan Sunggal terdiri dari 18 (delapan belas) lingkungan, salah satu yang menjadi lokasi penelitian adalah lingkungan 18 (delapan belas) memiliki 408 jiwa dengan jumlah 93 kepala keluarga.

Perkampungan KODAM I Medan Sunggal memiliki 18 (delapan belas) lingkungan yang di atasi oleh komadan komplek (DANPLEK), sebagaimana setiap perizinan melalui DANPLEK untuk menuju pada tahap KORAMIL kemudian dari KORAMIL di atasi oleh KODIM 0201/BS dan KODIM 0201/BS merupakan sebagai pihak yang bertanggung jawab terhadap perkampungan KODAM I Medan Sunggal, melalui KODIM 0201/BS peneliti mendapatkan izin secara mutlak untuk terjun ke lapangan dan mengenai segala data yang ada di perkampungan KODAM I Medan Sunggal.

Mata pencaharian yang paling banyak di perkampungan KODAM I/BB Medan Sunggal adalah 39.81 persen masyarakat bekerja sebagai TNI hal ini menujukan bahwa pekerja terbanyak adalah sebagai TNI, 29.10 persen masyarakat bekerja sebagai pegawai negeri. Hal ini dibuktikan 
dengan tipe perkampungan KODAM I Medan Sunggal yang banyak bekerja sebagai abdi/pegawai negara, 20.81 persen masyarakat mencari nafkah sebagai pegawai swasta sebagian besar dari istri atau anak yang masih tinggal bersama ayah atau ibunya, $\quad 1.20$ persen sebagai petani/nelayan, 1,85 persen bekerja sebagai pedagang, 0.86 persen bekerja sebagai kepala lingkungan yang merupakan pensiunan dari $\mathrm{TNI} / \mathrm{militer}$, dan 3.54 persen sebagai ibu rumah tangga atau sedang berseklolah. dalam hal ini dibuktikan bahwa perekonomian di perkampungan KODAM I Medan Sunggal sudah termasuk stabil dan dikategorikan sangat baik.

Data-data

tersebut menunjukan bahwa rata-rata yang tinggal di Perakmpungan KODAM I BB Medan Sunggal bekerja sebagai anggota militer TNI, dan anggota TNI yang sudah memiliki keluarga secara merata sudah bekerja sebagai pegawai, pengusaha, dan ada pula yang mengikuti jejak dari ayahnya menjadi anggota militer TNI.

Secara perekonomian di perkampungan KODAM I BB Medan Sunggal sesuai dengan latar belakang keluarga dalam mengembangkan kecerdasan emosional anak tidak menjadikan dampak yang negatif bagi perekembangan anak, karena dari segi mata pencaharian orang tua, sudah membuat kondisi keluarga berkecukupan untuk memenuhi kehidupan sehari-hari.

Informan-informan yang peneliti temukan di lapangan hampir secara keseluruhan menyatakan bahwa upaya orang tua dan langkahlangkah dalam mengembangkan kecerdasam emosional anak ialah sebagai berikut:

Tabel 4.11. Rangkuman secara garis besar upaya orang tua, aspek dan faktor penghambat dan pendukung.

\begin{tabular}{|c|c|}
\hline $\begin{array}{l}\text { Upaya yang } \\
\text { dilakukan }\end{array}$ & $\begin{array}{l}\text { 1. Mengenali dengan jelas } \\
\text { emosional yang } \\
\text { berkembang pada anak. } \\
\text { 2. Menjadikan diri ayah atau } \\
\text { ibu lebih akrab dengan } \\
\text { anak. } \\
\text { 3. Mendorong anak agar } \\
\text { mau menceritakan } \\
\text { permasalahan yang } \\
\text { sedang diahadapinya. } \\
\text { 4. Mengajarkan kepada anak } \\
\text { dalam membaca situasi } \\
\text { sekitar. } \\
\text { 5. Mengajari anak untuk } \\
\text { berempati pada orang lain } \\
\text { 6. Bersikap adil kepada } \\
\text { anak-anak. } \\
\text { 7. Tidak menekan perasaan } \\
\text { anak ak anak } \\
\text { 8. Mengajarkan agar anak } \\
\text { tidak menghindar dan } \\
\text { jangan takut ditolak } \\
\text { dalam bergaul. } \\
\text { 9. Mengajarkan kepada anak } \\
\text { untuk bersikap rasional. } \\
\text { 10. Mengajarkan kepada anak } \\
\text { tentang humor dan canda } \\
\text { gurau dalam } \\
\text { berhubungan. }\end{array}$ \\
\hline $\begin{array}{l}\text { Aspek yang } \\
\text { dikembangk } \\
\text { an }\end{array}$ & $\begin{array}{ll}\text { 1. } & \text { Kesadaran diri } \\
\text { 2. } & \text { Mengolah emosi } \\
\text { 3. Membina hubungan } \\
\text { 4. Dan memberikan } \\
\text { motivasi terhadap anak }\end{array}$ \\
\hline $\begin{array}{l}\text { Faktor yang } \\
\text { mendukung. }\end{array}$ & $\begin{array}{l}\text { 1. Keluarga (orang tua, } \\
\text { Saudara kandung) yang } \\
\text { selalu membimbing. } \\
\text { 2. Pola asuh yang diberikan } \\
\text { kepada anak. } \\
\text { 3. motivasi dari keluarga } \\
\text { 4. Dan faktor lingkungan } \\
\text { berupa, tetangga, teman } \\
\text { sepergaulan dan } \\
\text { sekolah.yang mengacu } \\
\text { pada perbuatan positif } \\
\text { dalam beriteraksi antar } \\
\text { sesama }\end{array}$ \\
\hline
\end{tabular}




\begin{tabular}{|l|l|}
\hline $\begin{array}{l}\text { Faktor yang } \\
\text { menghamba }\end{array}$ & $\begin{array}{l}\text { 1. Minimnya perhatian dari } \\
\text { t }\end{array}$ \\
& $\begin{array}{l}\text { disebab atau ibu yang } \\
\text { bekerja }\end{array}$ \\
& $\begin{array}{l}\text { 2. Rendahnya motivasi dari } \\
\text { keluarga }\end{array}$ \\
& $\begin{array}{l}\text { 3. Sukar dalam berempati } \\
\text { 4. Sifat pendiam }\end{array}$ \\
\hline
\end{tabular}

Hasil rangkuman di atas merupakan hasil wawancara peneliti dengan keenam keluarga di perkampungan KODAM I/BB Medan Sunggal sebagai informan dan objek penelitian. Di mana hasil dari penelitian tersebut sudah menjawab secara keseluruhan dari tujuan penelitian pada tesis ini.

Kemudian dampak dari upaya yang telah dilakukan orang tua untuk mengembangkan kecerdasan emosional anak ialah anak akan lebih mengenal emosi pada diri dan kesadaran pada diri sendiri mampu mnyesuaikan diri terhadap perasaan yang sebenarnya terjadi, anak yang memiliki kecerdasan emosi tentunya memiliki rasa empati dan mudah bergaul antar sesama teman, sebagaimana yang peneliti temukan dilapangan, anak-anak lebih memiliki motivasi dalam belajar, saling berbagi antar teman, membantu teman dalam kesulitan, anak lebih bersikap proaktif terhadap teman yang suka menggangu dirinya, ketika dalam masalah yang menegangkan dan sulit bagi anak untuk menyelesaikan permasalahan, anak lebih memilih menceritakan kepada orang tua dan orang tua yang baik dalam mendidik emosional anak akan mengajarkan dengan cara yang sangat baik.

Islam mengajarkan bahwa anak merupakan amanah dari Allah Swt. Amanah tersebut sudah seharusnya menjadi kewajiban dan tanggung jawab bagi kedua orang tua, hal tersebut merupakan suatu wujud pertanggung jawaban kedua orang tua kepada Allah Swt. Dalam firmanNya banyak ayat yang menyerukan keharusan kedua orang tua menjaga dan mendidik semua anaknya, sebagaimana yang ditegaskan dala surat At-Tahrim ayat 6:

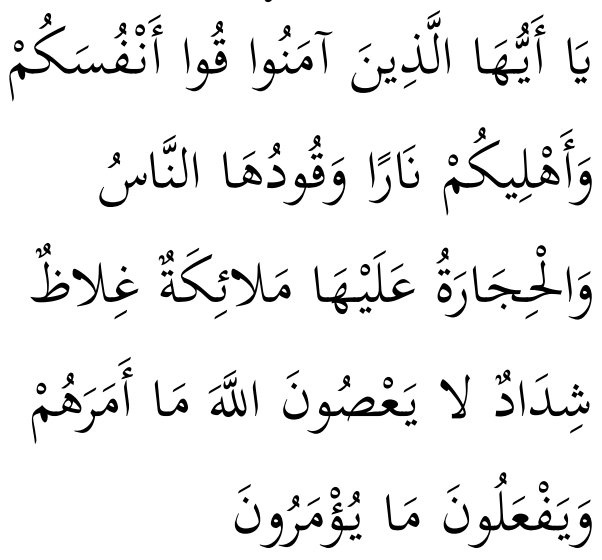

"Hai orang-orang yang beriman, peliharalah dirimu dan keluargamu dari api neraka yang bahan bakarnya adalah manusia dan batu; penjaganya malaikat-malaikat yang kasar, yang keras, yang tidak mendurhakai Allah terhadap apa yang diperintahkan-Nya kepada mereka dan selalu mengerjakan apa yang diperintahkan" (Depertemen Agama Republik indonesia, 2009)

$$
\text { Kesadaran }
$$

untuk mencerdasakan anak, tentulah dimiliki oleh setiap orang tua yang bijak. Betapa banyaknya orang tua bekerja keras, memabanting tulang, mencari biaya untuk menyekolahkan anak-anaknya agar menjadi cerdas. Sebagian diantara mereka bahkan rela hidup sederhana, mengorbankan apa yang bisa dikorbankan, untuk mendapatkan anak-anak yang didabakan ini. Tetapi persoalannya adalah bahwa pengorbanan dan kerja keras para orang tua yang mengharpakan anak-anak yang 
cerdas, seirngkali tidak disertai dengan kesadaran dan pengetahuan (know why and know how) yang memadai tentang mencerdasakandiri anak itu sendiri. (Surasono, 2000)

Selama preoses dalam
melakukan penelitian
perkampungan KODAM I/BB Medan
Sunggal untuk mengembangkan kecerdasan emosional anak mengacuh kepada poin-poin yang dikemukan oleh para ahli yaitu: (1) memahami atau membaca situasi, (2) mampu menyimak dan mendengarkan orang lain (3) siap bekomunikasi, (3) memiliki rasa empati, (5) siap mental dan tidak perlu takut untuk ditolak, (6) bersikap rasional dan fokus.

Dari beberapa poin diatas upaya-upaya untuk mengembangkan kecerdasan emosional anak yang dikemukakan oleh ahli merupakan acuan bagi keluarga agar mampu melakukan pendidikan terhadap anak terutama untuk kecerdasan emosional anak dapat berkembang dengan baik.

Terkait dengan faktor pendukung terhadap kecerdasan emosional anak ialah membina hubungan/komunikasi berhubungan baik antara anak dengan kedua orang tua atau hubungan anak dengan lingkungan dan hubungan dengan dirinya sendiri. Faktor penghambat merupaka faktor yang datang dari pergaulan dan muncul dari diri anak sendiri yang kurang dalam memahami diri sendiri sehingga anak memiliki emosi yang tidak terkendali, pergaulan yang buruk menjadikan anak yang nakal, faktor penghambat ini dapat diatasi dengan cara orang tua dapat memperhatikan bagaimana perkembangan emosional anak disetiap usianya sampai ia beranjak menuju dewasa.

Pada dasaranya lingkungan yang menjadi pendukung utama bagi anak dalam perkembangan emosinya merupakan lingkungan dari keluarganya itu sendiri, bukan dari lingkungan luar ataupun sekolah, oleh karenanya keluarga sudah searusnya mempersiapkan diri untuk mendidik anak sejak usia dini sebelum anak terjun kedunia luar agar anak lebih siap untuk menghadapi masalahmasalah kedirian yang akan terjadi pada dirinnya.

Orang tua yang mendidik anak dengan berupaya mengembangkan emosional (EQ) melalui kemampuan yang dimiliki anak untuk mengenali emosi diri sendiri, mengelolah emosi secara baik, rasa simpati, mampu berkomunikasi dengan baik, memiliki rasa empati yang tinggi, akan menjadi poin-poin penting bagi ayah dan ibu untuk menjadikan anak sukses dalam perjalanan hidup anak.

\section{Penutup}

1) Kesimpulan

Peranan orang tua dalam mengupayakan berbagai cara untuk mengembangkan kecerdasan emosional anak ialah ayah dan ibu lebih dominan sebagai contoh utama bagi anak tentunya akan berpengaruh terhadap diri anak untuk mengelola emosi yang ada pada dirinya, menyesuaikan diri terhadap keadaan lingkungan yang sedang dihadapinya atau situasi yang sedang berlangsung. Berbagai apek yang dikembangkan oleh orang tua dalam memberikan pembelajaran untuk mengembangkan kecerdasan emosionalnya adalah pengaturan/mengenali emosi diri, 
kemampuan memotivasi, kemampuan berempati dengan orang lain seperti keluarga, teman sebaya ataupun orang yang lebih tua darinya anak dapat mengelola emosi dengan baik.

\section{2) Saran}

Dari berbagai temuan dan teori yang dipaparkan di atas oleh karena itu peneliti memberikan saran kepada kedua orang tua yang merupakan pendidik bagi anak di dalam keluarga agar meluangkan sedikit banyaknya waktu untuk meberikan perhatian kepada anak, mengarahkan anak agar menjadikan anak lebih baik, harmonis membuat anak lebih nyaman dalam melakukan kegiatan belajar mengajar di lingkungan keluarga serta orang tua memberikan contoh kepada anak dalam keseharian seperti mengajarkan sifat penyabar, membantu orang lain dalam kesulitan dan hal-hal lain yang berkaitan dengan perasaan emosional. Dunia pendidikan yang pertama sekali dikenal anak adalah pendidikan di keluarga, maka sebagai orang tua yang bijak berikanlah pendidikan terbaik terutama dari segi emosionalnya sejak usia dini.

\section{Referensi}

Djamarah. 2004. Syamsul Bahri, Pola Komiunikasi orang tua dan anak dalam keluarga, Jakarta: Rineka Cipta.

Daulay. 2015. Nurussakinah. Psikologi Kecerdasan Anak, Medan: Perdana Publishing.

Depertemen Agama Republik Indonesia. 2009. Alquran dan Terjemahan, Bandung, syamil qur'an.
Goleman, Daniel. 2018. Emotional Intelegen, Jakarta: Gramedia Pustaka.

John w Santrock. 2011. Masa Perkembangan Anak, Jakarta: Salemba Humanika.

Kamus Lengkap Bahasa Indonesia. 2013. Jakarta: Tamer.

Lestari, Sri. 2012. Psikologi Kleuarga, Penanaman Nilai dan Penanganan Konflik Dalam Keluarga, Jakarta: Pernada Media Group.

Moh, A. 2017. The Development of Children's Social Emotional, Padang: Smart Print.

Prastowo, Andi. 2014. Metode Penelitian Kualitatif Dalam Perspektif Rancangan Penelitian, Yogyakarta: ArRuzz.

Syaukani. 2018. Metodelogi

Penelitian Pendidikan, Medan:

Perdana Publising.

Sugiyono. 2015. Metode Penelitian Pendidikan (Pendekatan Kuantitatif, Kualitatif dan $R \& d)$, Bandung: Alfabeta, cet. 22.

Surasono. 2000. Mencerdaskan Anak: Mesnsintesakan Kembai Intelegensi Umum (IQ) dan Intelegensi Emosional (IE) dengan Intelegensi Spritual, Jakarta: Inisiasi Press.

Undang-undang Sitem Pendidikan Nasional. 2008. Jakarta: Sinar Grafika. 